\title{
Impact of atmospheric deposition of anthropogenic and natural trace metals on Northwestern Mediterranean surface waters: A box model assessment
}

\author{
Lars-Eric Heimbürger $^{\text {a,b,c,*,1}}$, Christophe Migon ${ }^{\text {a,b }}$, Daniel Cossa ${ }^{c}$ \\ a UPMC Université Paris 06, UMR 7093, LOV, Observatoire océanographique, F-06234 Villefranche-sur-Mer, France \\ ${ }^{\mathrm{b}}$ CNRS, UMR 7093, LOV, Observatoire océanographique, F-06234 Villefranche-sur-Mer, France \\ ' IFREMER, Centre de Méditerranée, BP 330, F-83507 La Seyne-sur-Mer, France \\ The balance between atmospheric deposition and removal from surface waters shows that metals such as Cd, Cr, Ni are efficiently removed, while \\ others $(\mathrm{Hg}, \mathrm{Pb}, \mathrm{Zn})$ accumulate in Ligurian surface waters.
}

\section{A R T I C L E I N F O}

\section{Article history:}

Received 23 November 2010

Received in revised form

24 February 2011

Accepted 26 February 2011

\section{Keywords:}

Atmospheric deposition

Trace metal pollution

Box model

Northwestern Mediterranean

Impact evaluation

Environmental antipollution policies

\begin{abstract}
A B S T R A C T
Under stratified oligotrophic conditions (May-November), the surface mixed layer of the Northwestern Mediterranean constitutes a homogeneous water volume of 10-30 m depth. In other respects, the mean residence time of Ligurian surface waters $(0-200 \mathrm{~m})$ is 102 days. It is therefore possible to quantify the extent to which atmospheric deposition of trace metals affects surface waters. On the basis of literature data on anthropogenic and natural trace metals, we demonstrate that the ratios between total seawater labile atmospheric deposition during 102 days $(\Delta c)$ and dissolved TM concentrations in Ligurian surface waters $(c)$ illustrate the impact of atmospheric deposition on surface seawater $(\Delta c / c)$. High ratios indicate surface TM enrichments, while low ratios indicate surface TM depletion, due to the quasi-complete sorption and removal of TMs by plankton during spring bloom. The simple box model proposed here may be used for other marine regions where hydrodynamical and physico-chemical constraints are well defined.
\end{abstract}

(c) 2011 Elsevier Ltd. All rights reserved.

\section{Introduction}

The most efficient transport route to spread contaminants over open waters is the atmospheric pathway (e.g., Boutron et al., 1991; Jickells, 1995). This is particularly acute for the Western Mediterranean Sea, which is subject to intense particulate and dissolved atmospheric TM inputs, including anthropogenic inputs from Northeastern and Central Europe and pulsed Saharan dust events of natural crustal material from Northern Africa (Guieu et al., 1997; Guerzoni et al., 1999). Chester et al. (1997) have described this marine region as the combination of Saharan inputs and diffuse European anthropogenic emissions. As a result, trace metal (TM) concentrations in Mediterranean surface waters are higher than in the open ocean, e.g. the Atlantic Ocean (Boyle et al., 1985; Morley et al., 1997).

Owing to its reduced dimensions (surface area: $0.53 \times 10^{11} \mathrm{~m}^{2}$ ), and numerous and intense land-based emission sources along its densely populated shores ( 300 inhabitant per $\mathrm{km}^{2}$, UNEP, 2004; Laubier, 2005), the Ligurian Sea (Northwestern Mediterranean) is

\footnotetext{
* Corresponding author.

E-mail address: heimburger@get.obs-mip.fr (L.-E. Heimbürger).

${ }^{1}$ Present address: Geosciences Environment Toulouse (GET), Observatoire MidiPyrénées (OMP), 14 Ave. E. Belin, F-31400 Toulouse, France.
}

particularly subject to atmospheric TM inputs. As a matter of fact, the TM distribution patterns in the water column suggest that the atmospheric TM inputs govern their biogeochemical cycling (Béthoux et al., 1990; Migon et al., 2002).

In spite of stricter antipollution policies, the on-going industrialization of Europe (in particular Eastern Europe) and Southern Mediterranean countries will probably lead to increasing atmospheric TM inputs on the Ligurian Sea. On the basis of literature data, the present paper deals with the TM enrichment of Ligurian surface waters and therefore evaluate the actual impact of atmospheric pollution on the ocean. Although many papers have already dealt with the atmospheric TM deposition on various marine areas (e.g., Jickells, 1999; Guerzoni et al., 1999; Brown et al., 2005; Measures et al., 2005, 2008), the present work proposes a simple box model assessing the impact of the atmospheric input of TMs on an oligitrophic stratified surface layer, using the Ligurian Sea as an example.

\section{Materials and methods \\ 2.1. Circulation in the Ligurian Sea}

The Ligurian Sea is subject to a permanent cyclonic circulation (Fig. 1). The surface flux $(0-200 \mathrm{~m})$ of Atlantic waters ascending along the northwestern coast of 


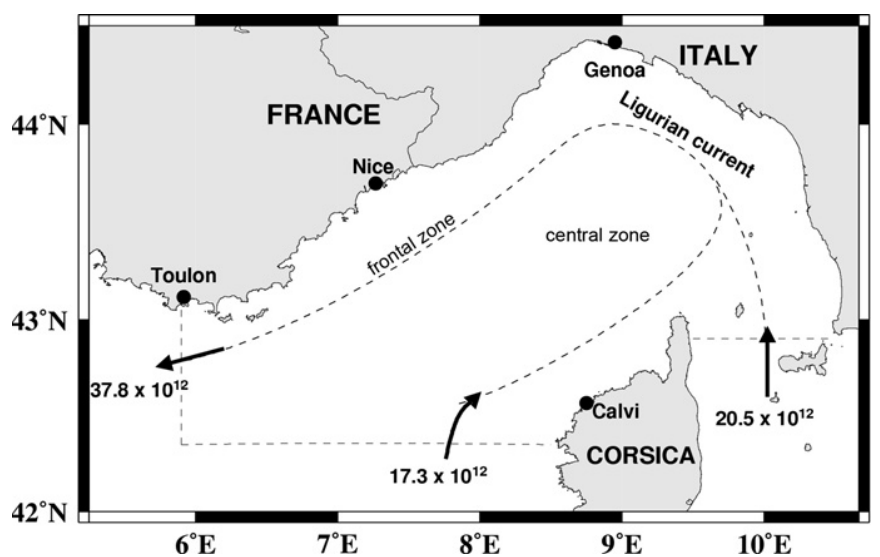

Fig. 1. Location (rectilinear dotted lines) and cyclonic circulation of the Ligurian Sea. Incoming and outgoing water flows are expressed in $\mathrm{m}^{3} \mathrm{yr}^{-1}$. The boundaries of the Ligurian Sea area are those commonly used in literature (e.g., Béthoux, 1980; Béthoux et al., 1988).

Corsica is $17.3 \times 10^{12} \mathrm{~m}^{3}$ year $^{-1}$ (Béthoux, 1980). This flux encounters that coming from the Tyrrhenian Sea $\left(20.5 \times 10^{12} \mathrm{~m}^{3}\right.$ year $\left.^{-1}\right)$ via the Corsica channel. The mixing of the two fluxes generates the Ligurian current (LC) that flows in the direction NESW along the Riviera and exits the Ligurian Sea with a flow of $37.8 \times 10^{12} \mathrm{~m}^{3}$ year $^{-1}$. For a $0-200 \mathrm{~m}$-deep surface layer, the volume $V$ of surface waters of the Ligurian Sea is $0.53 \times 10^{11} \mathrm{~m}^{2} \times 200 \mathrm{~m}=10.6 \times 10^{12} \mathrm{~m}^{3}$

Apart from vertical mixing during short episodes in winter, the residence time of surface waters in the Ligurian area $\left(t_{\mathrm{R}}\right)$ can be computed as:

$t_{\mathrm{R}}=V / \mathrm{LC}$

and is equal to 0.28 year (102 days). During this relatively long period, surface waters form a homogeneous water volume (Béthoux, 1980). It is therefore possible to evaluate the extent to which atmospheric deposition is able to affect surface waters during their transit through the Ligurian Sea.

A frontal zone with rapid horizontal change of density separates offshore Ligurian waters from the coast (Lévy et al., 1998). Apart from exceptional hydrodynamic conditions the central Ligurian Sea is sheltered from lateral inputs (Béthoux et al., 1988; Marty pers. comm.). For this reason, the atmosphere is believed to be the only significant source of TMs to the open Ligurian Sea. This marine region has been used several times to study the impact of atmospheric fluxes on marine systems (e.g., DYFAMED and MEDFLUX); and two special issues have been dedicated to this time-series station (Marty, 2002; Lee et al., 2009).

\subsection{Presentation of the box model}

A box model was used to estimate the impact of total seawater labile atmospheric TM deposition on the surface ocean chemistry of the Ligurian Sea over the period during which the water column is highly stratified and a homogeneous mixed layer (ML) exists (Lacroix and Grégoire, 2002; Pulido-Villena et al., 2008). Literature data from the Ligurian region (atmospheric TM fluxes and dissolved surface water TM concentrations) were used.

The data of total seawater labile atmospheric flux of TMs $\left(F_{\mathrm{TM}}\right)$ and the corresponding references are presented in Table 1 . The cited works estimated the total seawater labile fraction, i.e. the fraction likely to be dissolved into seawater, through different approaches from land-based measurements of the total atmospheric TM deposition (refer to Table 1). We used this fraction here to compute the enrichment of the ML during this period of 102 days for each TM. The mean increase of TM concentrations in the surface layer $(\Delta c)$ may be expressed by:

$\Delta c=\left[F_{\mathrm{TM}} \times t_{\mathrm{R}}\right] / z$

where $F_{\mathrm{TM}}\left(\mu \mathrm{g} \mathrm{m}^{-2} \mathrm{~d}^{-1}\right)$ is the seawater labile atmospheric flux of a given TM, for $t_{\mathrm{R}}=102$ days and $z$ is the depth in meters of the homogeneous ML.

The $z$ value should be considered only when the heating of surface waters leads to the formation of the thermocline, which isolates the ML from underlying waters and, therefore yields the existence of a homogeneous ML. Such conditions occur in the Northwestern Mediterranean from the end of May to November, approximately (Marty et al., 2002; Heimbürger et al., 2010a). Nutrient resources are rapidly depleted and the biological activity concurrently decreases. In such oligotrophic conditions, dissolved TM are not significantly assimilated by biota or packaged with particulate organic matter and, therefore, accumulate in the ML (Migon et al., 2002). The depth of the ML in stratified conditions varies between 10 and $30 \mathrm{~m}$ (Andersen and Prieur, 2000; Marty et al., 2002, 2008). The dilution of the TM atmospheric load
Table 1

Mean inputs of seawater labile TMs to the Ligurian Sea, expressed in $\mu \mathrm{g} \mathrm{m}^{-2} \mathrm{~d}^{-1}$.

\begin{tabular}{|c|c|c|c|c|}
\hline \multirow[t]{2}{*}{ TM } & \multicolumn{4}{|c|}{ Total seawater labile atmospheric deposition $\left(F_{\mathrm{TM}}\right)$} \\
\hline & Individual st & & & Summary \\
\hline $\mathrm{Al}$ & $28-279^{a}$ & & & $28-279$ \\
\hline $\mathrm{Cd}$ & $0.12^{\mathrm{b}}$ & $0.16^{\mathrm{c}}$ & & $0.12-0.16$ \\
\hline Co & $0.05-0.36^{\mathrm{a}}$ & $0.15^{\mathrm{b}}$ & & $0.05-0.36$ \\
\hline $\mathrm{Cr}$ & $0.25-1.10^{\mathrm{a}}$ & $1.30^{\mathrm{c}}$ & & $0.25-1.30$ \\
\hline $\mathrm{Cu}$ & $2.19-3.56^{\mathrm{a}}$ & $1.86-2.88^{\mathrm{b}}$ & $3.2^{\mathrm{c}}$ & $1.86-3.56$ \\
\hline $\mathrm{Fe}$ & $89-384^{\mathrm{a}}$ & $6.4^{\mathrm{d}}$ & & $6.4-384$ \\
\hline $\mathrm{Hg}$ & $0.01-0.03^{\mathrm{e}}$ & $0.03^{f}$ & & $0.01-0.03$ \\
\hline $\mathrm{Ni}$ & $1.1-1.4^{\mathrm{a}}$ & $1.63-1.92^{\mathrm{b}}$ & $2.6^{\mathrm{c}}$ & $1.1-2.6$ \\
\hline $\mathrm{Pb}$ & $2.5-5.2^{\mathrm{a}}$ & $2.58-5.07^{b}$ & & $2.5-5.2$ \\
\hline $\mathrm{Zn}$ & $77-165^{\mathrm{b}}$ & $107^{c}$ & & $77-165$ \\
\hline
\end{tabular}

${ }^{\text {a }}$ Guieu et al. (1997).

b Values computed from total fluxes from Migon et al. (1997) and dissolvedparticulate partitioning from Guieu et al. (1997).

c Seawater labile estimations according to Sandroni and Migon (2002).

d Bonnet and Guieu (2006).

e Mean Mediterranean values, non specific to the Ligurian Sea by Cossa and Coquery (2005).

${ }_{\mathrm{f}}$ Mean Mediterranean values, non specific to the Ligurian Sea by Rajar et al (2007).

in surface seawater should thus be considered within a maximum ML depth of $30 \mathrm{~m}$ $\Delta c$ values computed using the range of atmospheric TM fluxes with $z$ ranging between 10 and $30 \mathrm{~m}$ are both given in Table 2 . The impact of the atmospheric input of seawater labile TMs on the ML can then be computed as $\Delta c / c$, using the range of marine dissolved TM concentrations $(c)$ from literature data (Table 2).

The aims of this box model could be applied to other hydrodynamic marine environments where physico-chemical constraints may be well defined (epicontinental seas, Gulf of Thailand, Gulf of St Lawrence or Gulf of Mexico, Bering Sea, China Sea, Okhotsk Sea; e.g., Alexander et al., 1991; de Vernal et al., 2005).

\section{Results and discussion}

\subsection{Atmospheric deposition over the Ligurian Sea}

Trace metals are transferred from the troposphere to the sea surface by dry and wet deposition. The chemical composition of

Table 2

$\Delta c$ and $c$ values (both computed using the range of literature data), both expressed in $\mu \mathrm{g} \mathrm{m}^{-3}$, from which are computed $\Delta c / c$ ratios.

\begin{tabular}{lllll}
\hline $\mathrm{TM}$ & $\Delta c$ & $c$ & $\Delta c / c$ & Profile $^{\mathrm{j}}$ \\
\hline $\mathrm{Al}$ & $95-2850$ & $1349^{\mathrm{a}}$ & $7-211$ & Surface-enriched \\
$\mathrm{Cd}$ & $0.41-1.63$ & $7.3^{\mathrm{b}}$ & $5.6-22.3$ & Surface-depleted \\
& & $7.4^{\mathrm{c}}$ & $5.5-22$ & \\
& & $10.2-21.7^{\mathrm{d}}$ & $1.9-16$ & \\
$\mathrm{Co}$ & $0.17-3.67$ & $5.27^{\mathrm{d}}$ & $3.2-69.6$ & Surface-enriched \\
$\mathrm{Cr}$ & $0.85-13.3$ & $140^{\mathrm{e}}$ & $0.6-9.5$ & Surface-depleted \\
$\mathrm{Cu}$ & $6.32-36.3$ & $89-133^{\mathrm{f}}$ & $4.8-40.8$ & Surface-depleted/enriched \\
& & $89-127^{\mathrm{g}}$ & $5.0-40.8$ & \\
& & $127^{\mathrm{d}}$ & $5.0-28.6$ & \\
$\mathrm{Fe}$ & $22-3912$ & $14-67^{\mathrm{h}}$ & $33-28023$ & Surface-enriched \\
& & $67-112^{\mathrm{g}}$ & $20-5839$ & \\
$\mathrm{Hg}$ & $0.034-0.26$ & $-0.4^{\mathrm{i}}$ & $8.5-255$ & Surface-enriched \\
$\mathrm{Ni}$ & $3.74-26.5$ & $135-188^{\mathrm{g}}$ & $2.0-19.6$ & Surface-depleted \\
& & $212-299^{\mathrm{d}}$ & $1.3-12.5$ & \\
$\mathrm{~Pb}$ & $8.5-53.0$ & $35^{\mathrm{c}}$ & $24.3-151.4$ & Surface-enriched \\
& & $16.6-33.1^{\mathrm{g}}$ & $25.7-319$ & \\
$\mathrm{Zn}$ & $262-1683$ & $171^{\mathrm{c}}$ & $153-984$ & Surface-enriched \\
& & $111-216^{\mathrm{g}}$ & $121-1515$ & \\
\hline
\end{tabular}

a Chou and Wollast (1997)

b Lacan et al. (2006).

c Nicolas (1993).

d Heimbürger et al. (2009).

e Achterberg and van den Berg (1997).

f Riso et al. (1994).

$g$ Yoon et al. (1999).

h Bonnet and Guieu (2006).

i Cossa and Coquery (2005).

j Refer to Fig. 2 for meaning. 
atmospheric TM deposition on sea surface waters strongly depends on that of the aerosol (Chester et al., 1997, 1999). Potential spatial and temporal (e.g., seasonal) variations in the atmospheric TM input must be considered before trying to budget the TM deposition to the Ligurian Sea. Taking into account the variability of local meteorological and climatological conditions (rainfall amount, speed of prevailing winds, efficiency of the aerosol scavenging, etc.), the spatial variability of atmospheric TM deposition is relatively low: the regional atmospheric input is superimposed to a strong background aerosol originating from industrialized regions of Europe (Chester et al., 1997). For example, the lowest spatial variability in the Ligurian atmospheric aerosol (nickel (Ni) concentrations) ranges within a factor of 1.4 , and the highest variability (aluminum ( $\mathrm{Al}$ ) concentrations) ranges within a factor of 3.2 (Sandroni and Migon, 1997). Atmospheric TM fluxes at coastal sites may therefore be extrapolated to the sub-basin scale, as shown by comparison with shipboard aerosol sample collection (Jickells, 1995). The shipboard collection of aerosols is difficult over long time scales and, therefore, coastal or island based measurements are generally used (e.g., Chester et al., 1999; Güllü et al., 2000; Bonnet and Guieu, 2006). However, atmospheric TM deposition exhibits a seasonal pattern. In particular, anthropogenic TM emissions from Northern or Northeastern Europe are strong in the Northwestern Mediterranean area at the end of winter (Avila and Alarcon, 1999; Heimbürger et al., 2010b). This is consistent with the advective transport of polluted air masses from Europe as modeled by Duncan and Bey (2004). However, the Ligurian Sea might be even more strongly affected by such anthropogenic land-based emissions at the beginning of autumn, due to the autumnal equinox that points to the moving of the polar front to the southward, yielding the arrival of air masses from Northern and/or North-Eastern industrialized regions of Europe to the Western Mediterranean (Barnaba and Gobbi, 2004).

The isolation of Mediterranean waters from Atlantic waters enhances the role of atmospheric TM inputs and, therefore, the role of local driving forces such as climate, meteorology and environment (Béthoux et al., 1999). This strongly determines the occurrence of wet and dry atmospheric TM deposition and, therefore, the physico-chemical form (dissolved or particulate) under which atmospherically transported TMs enter the sea surface. Due to the scarcity of rain events over the whole year, the dry deposition mode is dominant in the Mediterranean Sea for the majority of TMs (Nicolas et al., 1995), except for some soluble anthropogenic TMs that are significantly transported to the Northwestern Mediterranean by Northern and Northeastern European polluted air masses during winter and autumn, i.e. the wet season. In addition, these soluble TMs are efficiently incorporated into rainwater, and therefore their cycling is strongly influenced by wet deposition. For example, the wet contribution of $\mathrm{Cd}$ and $\mathrm{Zn}$ may represent up to 50 and $48 \%$, respectively, of the total atmospheric fluxes in Ligurian coastal areas, to be compared with the wet contribution of Co (26\%) or Cu (27\%) (Migon et al., 1997).

The solubilization of atmospheric particles into seawater greatly determines the involvement of TMs in marine biogeochemical cycles. Seawater solubility of TMs is believed to be related to the two following parameters:

i) The source-dependent composition of aerosol particles (anthropogenic vs. crustal). Basically, crustal TMs are associated with the high loading of coarse particles, within threedimensional crystalline networks in which dissolution is low. On the other hand, anthropogenic TMs are associated with the low loading of small amorphous particles that are much more soluble (Chuang et al., 2005; Sedwick et al., 2007).

ii) Atmospheric solubilization processes that occur during the aerosol transport. Experimental studies (e.g., Spokes and
Jickells, 1995; Hand et al., 2004) suggest that the solubility of aerosol TMs in the ocean surface may be increased by photo-reduction and $\mathrm{pH}$ variations. However, field evidence for the dissolution of aerosols under such conditions in the atmosphere is still lacking (Mahowald et al., 2009; Sholkovitz et al., 2009). For this reason, atmospheric fluxes of "seawater labile" TMs over the Ligurian Sea (Table 1) are estimated from a variety of literature data that are not only based on $\mathrm{pH}-$ driven laboratory experiments.

\subsection{Impact of the atmospheric input on surface water concentrations}

Even if the conditions of stratification of the surface layer, which determine the confinement of atmospheric loads, are variable in space and time, the evaluations given in Table 2 permit us to roughly quantify the potential impact of atmospheric TM deposition. Such TM enrichments of the Ligurian surface layer represent mean situations. Higher $\Delta c$ values may probably be expected over shorter spatial and temporal scales, when strong atmospheric events occur (e.g., Saharan dust storms or intense anthropogenic episodes).

Assuming that the residence time of TMs in offshore surface waters is shorter than (or equal to) deep-water renewal time (Nicolas et al., 1998), vertical dissolved TM distributions in the western Mediterranean chiefly depend upon atmospheric TM fluxes. Therefore, the atmospheric TM flux during the stratification period in the Ligurian Sea (i.e., basically, from May to November) determines the TM concentrations above the thermocline.

Typically, when atmospheric TM deposition significantly impacts surface waters, TMs presumably exhibit surface-enriched profiles (e.g., Co, Fig. 2a). On the contrary, when atmospheric TM enrichment is low, TMs may exhibit surface-depleted profiles (e.g., $\mathrm{Ni}$, Fig. 2b). This results from the more or less efficient removal of dissolved TMs to depth. Recent measurements of dissolved TM concentration profiles in the Ligurian Sea (Heimbürger et al., 2009) are in agreement with this statement and suggest that either surface-depleted or surface-enriched profiles (Fig. 2a,b) are expected for TMs, according to the significance of their accumulation in ML, relative to the seasonal efficiency of the vertical transfer (Migon and Nicolas, 1998).
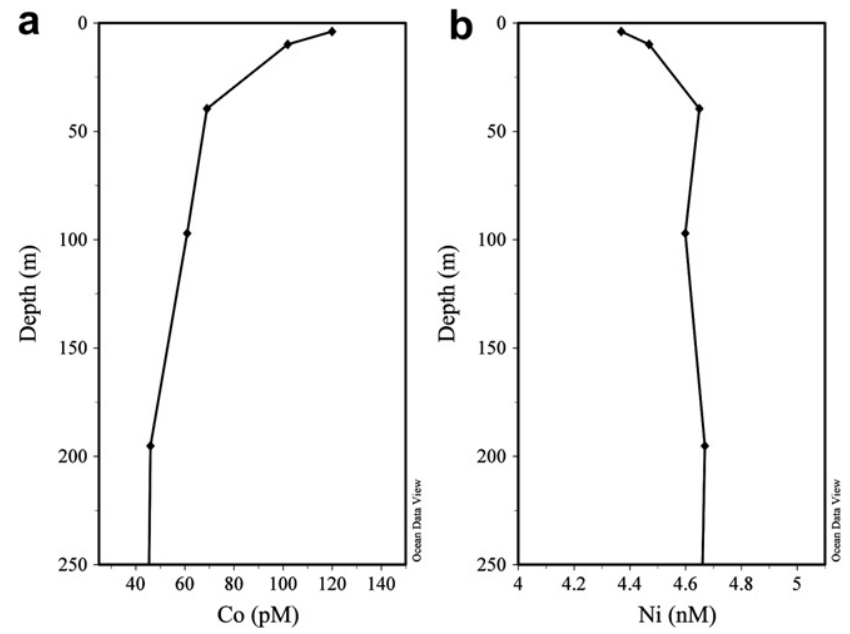

Fig. 2. Dissolved Co and Ni profiles during the Ligurian stratification period (October 2007, DYFAMED site, central Ligurian Sea, $43^{\circ} 25^{\prime} \mathrm{N}, 7^{\circ} 52^{\prime} \mathrm{E}$ ), data from Heimbürger et al. (2009). Cobalt (a) represents a typical surface-enriched profile. Nickel (b) represents a typical surface-depleted profile. 
Surface-depleted TM profiles suggest that the deposition flux of the considered TM is insufficient to compensate for the biological removal that has occurred in spring, when primary production was high, until the beginning of the stratification period, when the ML has become nutrient-depleted. On the other hand, surfaceenriched profiles suggest that the overall removal potential of biological activity and passive particle-surface removal is not efficient enough to remove dissolved TMs from the surface layer within the duration of Ligurian water residence time. In this second case the removal of dissolved TMs from ML thus depends on hydrological processes, i.e. winter vertical mixing (Migon et al., 2002).

\subsubsection{Iron}

Iron enrichments exhibit a very high variability (Table 2 ). Factors within the water column (e.g., $\mathrm{pH}$, ligand concentration, biological uptake) may contribute to the variability of $\mathrm{Fe}$ enrichment. However, in the Mediterranean Sea, such marine parameters are of very little weight compared with the temporal variability of atmospheric inputs, due to changes in aerosol source (anthropogenic versus natural) and, in particular, the pulsed character of Saharan dust events. Bonnet and Guieu (2006) have shown that over $99 \%$ of the total 2004 flux of total atmospheric Fe can be attributed to a few strong pulses of Saharan dust events. As a consequence, the interannual variability of crustal inputs (and, therefore, Al and Fe inputs) is very high (Guieu et al., 2010). It is believed that the wide range of $\Delta c / c$ values observed for Fe and, to a lesser extent, for $\mathrm{Al}$, is due to variability in $\mathrm{Fe}$ and $\mathrm{Al}$ flux estimations. For example, the flux value proposed by Bonnet and Guieu (2006) was essentially based on a single Saharan event that brought up to $88 \%$ of total atmospherically-deposited Fe. However, if Saharan dust episodes are the most important source of atmospheric Fe, the actual flux of seawater labile Fe might be significantly overestimated, because of the low solubility of crustal Fe. For example, seawater labile Fe fluxes given by Guieu et al. (1997) were computed from literature on dissolved-particulate partitioning factors, in which the dissolved fraction is believed to be overestimated (Guieu, pers. comm.). Despite these uncertainties, high $\Delta c / c$ values result to a large extent from strong Fe and $\mathrm{Al}$ atmospheric deposition, compared with seawater concentrations. This suggests an accumulation in surface waters, which yields surfaceenriched profiles (Table 2). Several oceanic regions exhibit surfacedepleted profiles of dissolved $\mathrm{Fe}$, even when they are heavily impacted by dust events. For example, Measures et al. (2008) found increased Fe concentrations in Atlantic $\left(62^{\circ} \mathrm{N}, 5^{\circ} \mathrm{S}\right)$ surface waters beneath Saharan dust outflows, but high dissolved Fe concentrations $(>1.5 \mathrm{nM})$ in subsurface layers yielded surface-depleted profiles. However, the Ligurian Sea exhibits a different behavior: Bonnet and Guieu (2006) noticed that the atmospheric input of dissolved Fe actually accumulates in surface waters, with no significant loss from the ML, to reach its maximum around October, while subsurface concentrations were lower. As a result, Fe profiles were either rectilinear or surface-enriched. This implies that recognized Fe-depleting processes such as phytoplankton uptake/ adsorption, scavenging onto sinking particles or diffusion through the thermocline are negligible during the oligotrophic stratified period. The surface accumulation of Fe occurs during a time of minimal or lower Fe uptake during the period as nutrient supply has been exhausted, i.e. the oligotrophic period.

\subsubsection{Lead}

The observed variability of atmospheric lead $(\mathrm{Pb})$ fluxes mirrors the rapid decrease of $\mathrm{Pb}$ concentration in the Mediterranean environment since 1988 (Migon et al., 2008). Since the implementation of antipollution policies on automotive $\mathrm{Pb}$ in the mid- 1980s, the concentration levels of $\mathrm{Pb}$ in the atmosphere and in Mediterranean waters have decreased sharply within a few years (Migon and Nicolas, 1998). This atmospheric decrease has continued since that time (Migon et al., 2008; Heimbürger et al., 2010b). Therefore, it is likely that the present-day impact of atmospheric $\mathrm{Pb}$ inputs is lower than $\mathrm{Pb}$ enrichments estimated in Table 2 (surface-enriched profile). Present-day $\Delta c / c$ variability is presumably lower than that observed in Table 2 as well, because of the slight temporal shift between the references used here. For example, Guieu et al. (1997) gather results that do not correspond to the same sampling period, and the range of values given by Yoon et al. (1999) correspond to more recent data, compared with the values of Nicolas (1993).

\subsubsection{Zinc}

The atmospheric $\mathrm{Zn}$ fluxes used in the present box model yield high $\Delta c / c$ values, suggesting enrichments relative to the dissolved $\mathrm{Zn}$ concentrations in surface water. Zinc is mainly of urban origin, most of which comes from motor vehicle use, owing to tire wear (Wiesner et al., 1998), and the Ligurian Sea is subject to significant emission sources from the large urbanized area between Toulon and Genoa. In addition, significant amounts of $\mathrm{Zn}$ are emitted by waste incinerations (Nriagu and Pacyna, 1988), which are probably a noticeable source of $\mathrm{Zn}$, particularly when waste plant residual muds are incinerated (Migon and Sandroni, 1999). However, dissolved Zn profiles measured in the Western Mediterranean show contradictory behaviors: Data from Ruiz-Pino et al. (1991) show surface-enriched dissolved Zn profiles with a subsurface minimum, while data from Yoon et al. (1999) show surface-depleted dissolved Zn profiles, with a subsurface maximum. Keeping in mind that contamination problems are always acute for $\mathrm{Zn}$ (including atmospheric measurements), the reliability of these data and their subsequent interpretation for $\mathrm{Zn}$ behavior in surface waters therefore remains questionable. More data on $\mathrm{Zn}$ atmospheric deposition and water column distribution is urgently needed. However $\mathrm{Zn}$ aerosol concentrations in the Northwestern Mediterranean have decreased by $54 \%$ over the past 2 decades (Heimbürger et al., 2010b), thus the deposition flux of seawater labile $\mathrm{Zn}$ is likely to be reduced as well and that might significantly change the $\Delta c / c$ values.

\subsubsection{Mercury}

The case of $\mathrm{Hg}$ deserves special consideration, since the atmosphere is known as the main transport medium of this element to the open sea. In the same way, phytoplankton uptake and abiotic sorption are not the main, and in no case the only removal process of this TM from surface seawater in many biogeochemical conditions (see the review by Fitzgerald et al., 2007). Indeed, it is well established that elemental $\mathrm{Hg}$ evolves in the atmosphere as a result of the photochemical and microbiological reduction of $\mathrm{Hg}^{\mathrm{II}}$ present in marine surface waters (e.g., Mason et al., 2001). This peculiarity of the $\mathrm{Hg}$ cycle applied to our model would lead to the risk of obtaining $\Delta c / c$ ratios inconsistent with the $\mathrm{Hg}$ profiles observed in the water column, a surface-depleted profile possibly reflecting not only the efficiency of biological or chemical scavenging processes, but also removal by $\mathrm{Hg}$ escaping from the sea surface into the air. However, the surface-enriched profiles actually observed suggest that $\mathrm{Hg}$ deposition in the Ligurian Sea is significant enough to overcome its evasion and the high $\Delta c / c$ ratios for $\mathrm{Hg}$ (Table 2) testify to the intensity of $\mathrm{Hg}$ deposition in the Ligurian Sea. The western Mediterranean basin is affected by $\mathrm{Hg}$-enriched air masses from regions of northern Europe, mainly as a result of coal combustion, caustic soda production, power plants and waste incineration (Pirrone et al., 2003; Pacyna et al., 2006), and by aeolian dust with low Hg content (Baturin et al., 1995). It is thought, from modeling, that scavenging by water droplets is an efficient removal pathway 
for atmospheric $\mathrm{Hg}$ after its (re)oxidation by halogen radicals within the marine boundary layer (Pirrone et al., 2003). However, according to the same authors, dry deposition (including gas transfer) may dominate on the Mediterranean Sea surface. Anyhow, in both wet and dry deposition, $\mathrm{Hg}$ is present mainly as divalent $\mathrm{Hg}$, which suggests that its solubilization in surface water is facilitated.

\subsubsection{Copper}

Copper, with a moderate $\Delta c / c$ ratio (up to 40.8), marks the boundary between surface-depleted and surface-enriched TM distribution profiles. Once $\Delta c / c$ ratios are computed, dissolved TM are examined. One can then estimate the interval within which these profiles shift from the depleted state to the enriched state. The threshold between one state and another is within this interval. It is then possible to know approximately where the edge is. Seawater labile $\mathrm{Cu}$ inputs to the Ligurian Sea are probably very close to the quantities that appear to be removed from surface waters by plankton activity. Indeed, surface-depleted dissolved $\mathrm{Cu}$ profiles were observed during the period of high biological productivity, i.e. spring bloom, while during the summer oligotrophic regime, $\mathrm{Cu}$ always presents surface-enriched profiles (Heimbürger et al., 2009).

The ratio between the magnitude of seawater labile TM atmospheric fluxes and the removal potential of biological activity may thus be a key parameter to control the shape of the dissolved TM vertical profiles, i.e. surface-depleted or surface-enriched.

The $\Delta c / c$ ratios presented above are related to the period of homogeneous ML. However, the atmospheric TM enrichment affects surface water concentrations at any other period of the year.

It is noteworthy that the two types of TM behavior observed in the Ligurian Sea (surface-enriched or surface-depleted) mirror a Mediterranean specificity: owing to the magnitude of atmospheric deposition over Mediterranean waters, the TM surface enrichment may exceed the ability of plankton to assimilate these TMs and, therefore, to transfer them to deep waters. On the other hand, TMs actively assimilated by phytoplankton are generally depleted in open ocean surface waters, either as a result of their quasi-complete assimilation by phytoplankton, or because they are packaged onto biological sinking material (Morel, 2008).

Ligurian waters are transported westwards with the LC and are further enriched on their pathway to be ultimately exported to the Atlantic Ocean. East of Gibraltar, the relative proportion of the Mediterranean outflow water (MOW) can be calculated on the basis of a conservative mixing with adjacent North Atlantic waters. During the mixing, $\mathrm{Cu}$ and $\mathrm{Ni}$ behave conservatively, while $\mathrm{Cd}$ is $\sim 80 \%$ conservative (Cotté-Krief et al., 2002). This means that advection controls $\mathrm{Cu}$ and $\mathrm{Ni}$ behaviors in the Atlantic Ocean. Since the Ligurian Sea is separated from the Alboran Sea where the MOW characteristics are formed by various hydrological features (cascading, fronts, etc.), and since, on the way to the Gibraltar strait, dense water formation (cascading) brings surface waters from the shelf with continental influence (Gulf of Lions) to depths (Riso et al., 2004; Canals et al., 2006), the influence of TM-enriched Ligurian waters seems very difficult to trace in the Atlantic Ocean.

A number of hydrological, chemical and biological processes interact to control the biogeochemical cycling and the distributions of TMs. The literature data used in the present model integrate these processes. The type of dissolved concentration profile exhibited by a given TM is inferred from the atmospheric enrichment of the surface: On the yearly scale, the biogeochemical cycle of TMs that exhibit surface-enriched vertical profiles is dominated by removal processes mediated by hydrology: because of significant atmospheric enrichment in the ML, the removal of dissolved TMs such as $\mathrm{Al}, \mathrm{Co}, \mathrm{Fe}, \mathrm{Hg}, \mathrm{Pb}$ and $\mathrm{Zn}$ from surface waters is mainly driven by winter convection. On the other hand, dissolved TMs that exhibit surface-depleted vertical profiles (e.g., $\mathrm{Cd}, \mathrm{Cr}$ and $\mathrm{Ni}$ ) are mainly removed from surface waters by their packaging with settling biological particles. The removal of dissolved $\mathrm{Cu}$ may be driven either by hydrology or biology, according to the seasonal intensity of primary production.

\section{Conclusions}

The use of $\Delta c / c$ ratios allows the quantification of the impact of individual TMs on surface waters. The present observations acquired in the Ligurian Sea permitted the construction of a model that should be suitable for the whole year and for marine regions constrained by physico-chemical atmospheric forcing. While $\mathrm{Cd}, \mathrm{Cr}$ and $\mathrm{Ni}$ do not cause any concern in terms of environmental pollution, other TMs, such as $\mathrm{Hg}, \mathrm{Pb}$ and $\mathrm{Zn}$, with elevated $\Delta c / c$ ratios, are not effectively removed from Ligurian surface waters during their passage and within their local residence time. Trace metals, which are surface-enriched (high $\Delta c / c$ ratios) might not only govern local settings at the sub-basin scale, but may be extended to the basin scale (i.e., the Western Mediterranean).

Trace metal cycling in the Mediterranean is known to be in a nonsteady-state equilibrium, with supposedly increasing anthropogenic constraints. Future meteorological and hydrological trends with changing climate, e.g. more or less winter mixing and more or less significant subsequent spring bloom, may also drastically change the impact of atmospheric fluxes on marine TM cycling. Consequently, future studies should comprise above all else continuous monitoring of atmospheric and marine TM concentrations.

\section{Acknowledgements}

We thank William Delor for language corrections. We thank the anonymous reviewers for their comments and suggestion which greatly improved the quality of this manuscript.

\section{References}

Achterberg, E.P., van den Berg, C.M.G., 1997. Chemical speciation of chromium and nickel in the western Mediterranean. Deep-Sea Res. II 44, 693-720.

Alexander, C.R., DeMaster, D.J., Nittrouer, C.A., 1991. Sediment accumulation in a modern epicontinental-shelf setting: the Yellow Sea. Mar. Geol. 98, 51-72.

Andersen, V., Prieur, L., 2000. One-month study in the open NW Mediterranean Sea (DYNAPROC experiment, May 1995): overview of the hydrobiogeochemical structures and effects of wind events. Deep-Sea Res. I 47, 397-422.

Avila, A., Alarcon, M., 1999. Relationship between precipitation chemistry and meteorological situations at a rural site in NE Spain. Atmos. Environ. 33, 1663-1677.

Barnaba, F., Gobbi, G.P., 2004. Aerosol seasonal variability over the Mediterranean region and relative impact of maritime, continental and Saharan dust particles over the basin from MODIS data in the year 2001. Atmos. Chem. Phys. 4, 2367-2391.

Baturin, G.N., Yemelyanov, E.M., Stryuk, V.L., Yushina, I.G., 1995. On chemical composition and material sources of oceanic suspensions. Oceanol. English Translation 35, 105-111.

Béthoux, J.P., 1980. Mean water fluxes across sections in the Mediterranean Sea, evaluated on the basis of water and salt budgets and of observed salinities. Oceanol. Acta 3, 79-88.

Béthoux, J.P., Courau, P., Nicolas, E., Ruiz-Pino, D., 1990. Trace metal pollution in the Mediterranean Sea. Oceanol. Acta 13, 481-488.

Béthoux, J.P., Gentili, B., Morin, P., Nicolas, E., Pierre, C., Ruiz-Pino, D., 1999. The Mediterranean Sea: a miniature ocean for climatic and environmental studies and a key for the climatic functioning of the North Atlantic. Progr. Oceanogr. 44, 131-146.

Béthoux, J.P., Prieur, L., Bong, J.H., 1988. Le courant ligure au large de Nice. Oceanol. Acta SN9, 59-67.

Bonnet, S., Guieu, C., 2006. Atmospheric forcing on the annual iron cycle in the western Mediterranean Sea: a 1-year survey. J. Geophys. Res. 111, C09010. doi:10.1029/2005JC003213

Boutron, C.F., Gorlach, U., Candelone, J.P., Bolshov, M.A., Delmas, R.J., 1991. Decrease of anthropogenic lead, cadmium, and zinc in Greenland snows since the late 1960s. Nature 353, 153-156.

Boyle, E.A., Chapnick, S.D., Bai, X.X., Spivack, A., 1985. Trace metal enrichments in the Mediterranean Sea. Earth Planet. Sci. Lett. 74, 405-419.

Brown, M.T., Landing, W.M., Measures, C.I., 2005. Dissolved and particulate Fe in the western and central North Pacific: results from the 2002 IOC cruise. Geochem. Geophys. Geosyst. 6 Q10001. 
Canals, M., Puig, P., de Madron, X.D., Heussner, S., Palanques, A., Fabres, J., 2006. Flushing submarine canyons. Nature 444, 354-357.

Chester, R., Nimmo, M., Corcoran, P.A., 1997. Rain water-aerosol trace metal relationships at Cap Ferrat: a coastal site in the Western Mediterranean. Mar. Chem. $58,293-312$.

Chester, R., Nimmo, M., Preston, M.R., 1999. The trace metal chemistry of atmospheric dry deposition samples collected at Cap Ferrat: a coastal site in the Western Mediterranean. Mar. Chem. 68, 15-30.

Chou, L., Wollast, R., 1997. Biogeochemical behaviour and mass balance of dissolved aluminium in the western Mediterranean Sea. Deep-Sea Res. II 44, 741-768.

Chuang, P.Y., Duvall, R.M., Shafer, M.M., Schaur, J.J., 2005. The origin of water soluble particulate iron in the Asian atmospheric outflow. Geophys. Res. Lett. 32, L07813. doi:10.1029/2004GL021946.

Cossa, D., Coquery, M., 2005. The Mediterranean mercury anomaly, a geochemical or a biological issue. In: Saliot, A. (Ed.), The Mediterranean Sea. Handbook of Environmental Chemistry, vol. 5. Springer, pp. 177-208.

Cotté-Krief, M.H., Thomas, A.J., Martin, J.M., 2002. Trace metal (Cd, Cu, Ni and $\mathrm{Pb}$ ) cycling in the upper water column near the shelf edge of the European continental margin (Celtic Sea). Mar. Chem. 79, 1-26.

de Vernal, A., Eynaud, F., HenryHillaire-Marcel, C., Londeix, L., Mangin, S., Matthiessen, J., Marret, F., Radi, T., Rochon, A., Solignac, S., Turon, J.L., 2005. Reconstruction of sea-surface conditions at middle to high latitudes of the Northern Hemisphere during the Last Glacial Maximum (LGM) based on dinoflagellate cyst assemblages. Quat. Sci. Rev. 24, 897-924.

Duncan, B.N., Bey, I., 2004. A modelling study of the export pathways of pollution from Europe: seasonal and interannual variations (1987-1997). J. Geophys. Res. 109, D08301. doi:10.1029/2003JD004079.

Fitzgerald, W.F., Lamborg, C.H., Hammerschmidt, C.R., 2007. Marine biogeochemical cycling of mercury. Chem. Rev. 107, 641-662.

Guerzoni, S., Chester, R., Dulac, F., Herut, B., Loÿe-Pilot, M.D., Measures, C., Migon, C., Molinaroli, E., Moulin, C., Rossini, P., Saydam, C., Soudine, A., Ziveri, P., 1999. The role of atmospheric deposition in the biogeochemistry of the Mediterranean Sea. Progr. Oceanogr. 44, 147-190.

Guieu, C., Chester, R., Nimmo, M., Martin, J.M., Guerzoni, S., Nicolas, E., Mateu, J., Keyse, S., 1997. Atmospheric input of dissolved and particulate metals to the north-western Mediterranean. Deep-Sea Res. II 44, 655-674.

Guieu, C., Loÿe-Pilot, M.D., Benyahya, L., Dufour, A., 2010. Spatial variability of atmospheric fluxes of metals ( $\mathrm{Al}, \mathrm{Fe}, \mathrm{Cd}, \mathrm{Zn}$ and $\mathrm{Pb}$ ) and phosphorus over the whole Mediterranean from a one-year monitoring experiment; biogeochemical implications. Mar. Chem. 120, 164-178.

Güllü, G.H., Olmez, I., Tuncel, G., 2000. Temporal variability of atmospheric trace element concentrations over the eastern Mediterranean Sea. Spectrochim. Acta Part B 55, 1135-1150.

Hand, J.L., Mahowald, N.M., Chen, Y., Siefert, R.L., Luo, C., Subramaniam, A., Fung, I., 2004. Estimates of atmospheric-processed soluble iron from observations and a global mineral aerosol model: biogeochemical implications. J. Geophys. Res. 109, D17205. doi:10.1029/2004JD004574.

Heimbürger, L.E., Chiffoleau, J.F., Dufour, A., Auger, D., Cossa, D., Migon, C., Marty, J.C., Coppola, L., 2009. Biogeochemical feedbacks in oligotrophic ocean water to atmospheric trace metal inputs. ASLO Aquatic Sciences Meeting, Nice (France).

Heimbürger, L.E., Cossa, D., Marty, J.C., Migon, C., Averty, B., Dufour, A., Ras, J., 2010a Methyl mercury distributions in relation to the presence of nano- and picophytoplankton in an oceanic water column (Ligurian Sea, North-western Mediterranean). Geochim. Cosmochim. Acta 74 (19), 5549-5559.

Heimbürger, L.E., Migon, C., Dufour, A., Chiffoleau, J.F., Cossa, D., 2010b. Trace metal concentrations in the North-western Mediterranean atmospheric aerosol between 1986 and 2008: seasonal patterns and decadal trends. Sci. Total Environ. 408 (13), 2629-2638.

Jickells, T.D., 1995. Atmospheric inputs of metals and nutrients to the oceans: their magnitude and effects. Mar. Chem. 48, 199-214.

Jickells, T.D., 1999. The inputs of dust derived elements to the Sargasso Sea; a synthesis. Mar. Chem. 68, 5-14.

Lacan, F., François, R., Ji, Y., Sherrell, R., 2006. Cadmium isotopic composition in the ocean. Geochim. Cosmochim. Acta 70, 5104-5118.

Lacroix, G., Grégoire, M., 2002. Revisited ecosystem model (MODECOGeL) of the Ligurian Sea: seasonal and interannual variability due to atmospheric forcing. J. Mar. Syst. 37, 229-258.

Laubier, L., 2005. Mediterranean Sea and humans: improving a conflictual partnership. In: Handbook of Environmental Chemistry, vol. 5. doi:10.1007/b107142 part K3-27.

Lee, C. Armstrong, R.A., Cochran, J.K., Engel, A., Fowler, S.W., Goutx, M., Masqué, P., Miquel, J.C., Peterson, M., Tamburini, C., Wakeham, S., 2009. MedFlux: investigations of particle flux in the Twilight Zone. Deep-Sea Res. II 56, 1363-1368.

Lévy, M., Mémery, L., André, J.M., 1998. Simulation of primary production and export fluxes in the Northwestern Mediterranean Sea. J. Mar. Res. 56, 197-238.

Mahowald, N.M., Engelstaedter, S., Luo, C., Sealy, A., Artaxo, P., Benitez-Nelson, C., Bonnet, S., Chen, Y., Chuang, P.Y., Cohen, D.D., Dulac, F., Herut, B., Johansen, A.M., Kubilay, N., Losno, R., Maenhaut, W., Paytan, A., Prospero, J.M., Shank, L., Siefert, R.L., 2009. Atmospheric iron deposition: Global distribution, variability and human perturbations. Annu. Rev. Mar. Sci. 1, 245-278.

Marty, J.C., 2002. The DYFAMED time-series program (French-JGOFS). Deep-Sea Res. II 49, 1963-1964.

Marty, J.C., Chiaverini, J., Pizay, M.D., Avril, B., 2002. Seasonal and interannual dynamics of nutrients and phytoplankton pigments in the western
Mediterranean Sea at the DYFAMED time-series station (1991-1999). Deep-Sea Res. II 49, 1965-1986.

Marty, J.C., Garcia, N., Raimbault, P., 2008. Phytoplankton dynamics and primary production under late summer conditions in the NW Mediterranean Sea. DeepSea Res. I 55, 1131-1149.

Mason, R.P., Lawson, N.M., Sheu, G.R., 2001. Mercury in the Atlantic Ocean: factors controlling air-sea exchange of mercury and its distribution in the upper waters. Deep-Sea Res. II 48, 2829-2853.

Measures, C.I., Brown, M.T., Vink, S., 2005. Dust deposition to the surface waters of the western and central North Pacific inferred from surface water dissolved aluminium concentrations. Geochem. Geophys. Geosyst. 6 Q09M03.

Measures, C.I., Landing, W.M., Brown, M.T., Buck, C.S., 2008. High-resolution Al and Fe data from the Atlantic Ocean CLIVAR- $\mathrm{CO}_{2}$ repeat hydrography $\mathrm{A} 16 \mathrm{~N}$ transect: extensive linkages between atmospheric dust and upper ocean geochemistry. Global Biogeochem. Cycles 22, GB1005. doi:10.1029/2007GB003042.

Migon, C., Journel, B., Nicolas, E., 1997. Measurement of trace metal wet, dry and total atmospheric fluxes over the Ligurian Sea. Atmos. Environ. 31A, 889-896.

Migon, C., Nicolas, E., 1998. Effects of antipollution policy on anthropogenic lead transfers in the Ligurian Sea. Mar. Pollut. Bull. 36, 775-779.

Migon, C., Robin, T., Dufour, A., Gentili, B., 2008. Decrease of lead concentrations in the western Mediterranean atmosphere during the last twenty years. Atmos. Environ. 42, 815-821.

Migon, C., Sandroni, V., 1999. Phosphorus in rainwater: partitioning, inputs and impact on the surface coastal ocean. Limnol. Oceanogr. 44, 1160-1165.

Migon, C., Sandroni, V., Marty, J.C., Gasser, B., Miquel, J.C., 2002. Transfer of atmospheric matter through the euphotic layer in the northwestern Mediterranean: seasonal pattern and driving forces. Deep-Sea Res. II 49, 2125-2142.

Morel, F.M.M., 2008. The co-evolution of phytoplankton and trace element cycles in the oceans. Geobiology 6, 318-324.

Morley, N.H., Burton, J.D., Tankere, S.P.C., Martin, J.M., 1997. Distribution and behaviour of some trace metals in the western Mediterranean Sea. Deep-Sea Res. II 44, 675-691.

Nicolas, E., 1993. Evolution of $\mathrm{Cd}, \mathrm{Pb}, \mathrm{Zn}$ concentrations in the Ligurian Sea since 1983. Ann. Inst. Oceanogr. 69, 119-122.

Nicolas, E., Béthoux, J.P., Migon, C., 1998. Geochemical implications of atmospheric lead decrease on the Mediterranean Sea environment. 23th EGS Genera Assembly, Nice (France), April 1998. Ann. Geophys. 16 C 733.

Nicolas, E., Migon, C., Leblond, N., Journel, B., 1995. Seasonality of dry and wet deposition of trace metals in the Ligurian Sea. Water Pollut. Res. Rep. 32, 275-285.

Nriagu, J.O., Pacyna, J.M., 1988. Quantitative assessment of worldwide contamination of air, water and soils by trace metals. Nature 333, 134-139.

Pacyna, E.G., Pacyna, J.M., Fudala, J., Strzelecka-Jastrzab, E., Hlawiczka, S., Panasiuk, D. 2006. Mercury emissions to the atmosphere from anthropogenic sources in Europe in 2000 and their scenarios until 2020. Sci. Total Environ. 370, 147-156.

Pirrone, N., Ferrara, R., Hedgecock, I.M., Kallos, G., Mamane, Y., Munth, J., Pacyna, J.M., Pytharoulis, I., Sprovieri, F., Voudouri, A., Wangberg, I., 2003. Dynamic processes of mercury over the Mediterranean region: results from the Mediterranean Atmospheric Mercury Cycle System (MAMCS) project. Atmos. Environ. 37, S21-S39.

Pulido-Villena, E., Wagener, T., Guieu, C., 2008. Bacterial response to dust pulses in the western Mediterranean: implications for carbon cycling in the oligotrophic ocean. Global Biogeochem. Cycles 22, GB1020. doi:10.1029/2007GB003091.

Rajar, R., Cetina, M., Horvat, M., Zagar, D., 2007. Mass balance of mercury in the Mediterranean Sea. Mar. Chem. 107, 89-102.

Riso, R.D., Le Corre, P., L'Helguen, S., Morin, P., 2004. On the presence of a cadmiumrich subsurface water mass in the western Mediterranean and its influence on the distribution of cadmium in the surface waters. Mar. Chem. 87, 15-22.

Riso, R.D., Le Corre, P., Morin, P., Cabon, J.Y., 1994. Vertical distribution of cadmium, copper and lead in the eastern Alboran Sea: enrichment of trace metals in surface waters. J. Mar. Syst. 5, 391-399.

Ruiz-Pino, D.P., Nicolas, E., Béthoux, J.P., Lambert, C.E., 1991. Zinc budget in the Mediterranean Sea: a hypothesis for non-steady-state behavior. Mar. Chem. 33, 145-169.

Sandroni, V., Migon, C., 1997. Significance of trace metal medium-range transport in the Western Mediterranean. Sci. Total Environ. 196, 83-89.

Sandroni, V., Migon, C., 2002. Atmospheric deposition of metallic pollutants over the Ligurian Sea: labile and residual inputs. Chemosphere 47, 753-764.

Sedwick, P.N., Sholkovitz, E.R., Church, T.M., 2007. Impact of anthropogenic combustion emissions on the fractional solubility of aerosol iron: evidence from the Sargasso Sea. Geochem. Geophys. Geosyst. 8. doi:10.1029/2007GC001586 Q10Q06.

Sholkovitz, E.R., Sedwick, P.N., Church, T.M., 2009. Influence of anthropogenic combustion emissions on the deposition of soluble aerosol iron to the ocean empirical estimates for island sites in the North Atlantic. Geochim. Cosmochim. Acta 73, 3981-4003.

Spokes, L.J., Jickells, T.D., 1995. Factors controlling the solubility of aerosol trace metals in the atmosphere and on mixing into seawater. Aquat. Geochem. 1, 355-374.

United Nations Environment Program, 2004. Mediterranean Action Plan MED POL Transboundary diagnostic analysis (TDA) for the Mediterranean Sea. UNEP MAP Publication, Athens.

Wiesner, M.R., Characklis, G.W., Brejchova, D., 1998. Metals and colloids in urban runoff. In: Allen, H.E., Garrison, A.W., Luther III, G.W. (Eds.), Metals in the Environment. Ann Arbor Press, pp. 23-35.

Yoon, Y.Y., Martin, J.M., Cotté, M.H., 1999. Dissolved trace metals in the Western Mediterranean Sea: total concentration and fraction isolated by C18 Sep-Pak technique. Mar. Chem. 66, 129-148. 